\title{
АПОПТОЗ І ПРОЛІФЕРАЦІЯ КЛІТИН ГІПЕРТРОФІЧНИХ І МОЛОДИХ КЕЛОЇДНИХ РУБЦІВ
}

\author{
๑Ю.Р. Барановський, В.М. Сегалов, А.У. Косенко \\ Кримський державний медичний університет ім. С.І. Георгієвського
}

РЕЗЮМЕ. У 35 пацієнтів хірургічного відділення Кримського регіонального управління клінічної лікарні ім. Н.А. Семашко, що перебували на стаціонарному лікуванні у зв'язку з необхідністю проведення різних повторних оперативних втручань в місці попередньої операції, інтраопераційно сікся післяопераційний келоїдний та гіпертрофічний рубець. Проліфератівну активність клітин епідермісу і дерми вивчали за допомогою моноклональних антитіл Ki-67 (MIB-1). Для оцінки процесів програмованої клітинної загибелі в келоїдних рубцях використовували моноклональні антитіла до Fas-рецепторів (CD 95 / Apo 1) і Bcl-2. Протеїн р53 використовувався для визначення числа клітин, що знаходяться у стадії апоптозу. У епідермісі гіпертрофічних рубців процеси апоптозу пригноблювані на тлі посиленої проліферації епідермоцитів, що приводить до його гіпертрофії. Збільшений вміст негативного регулятора апоптозу Bcl-2, що не дозволяє Fas-індукованим кератиноцитам вступити в апоптоз. У епідермісі молодих келоїдних рубців, незважаючи на активні процеси проліферації, кератіноціти активно елімінуються апоптозом, що стримує гіпертрофію епідермісу. У зоні зростання молодих келоїдних рубців спостерігається активна проліферація клітин, апоптоз яких інгібується Bcl-2.

КЛЮчОВІ СлОВА: келоїдний рубець, гіпертрофічний рубець, апоптоз, проліферація.

Вступ. Процеси загоєння ран приводять до рубцевих утворень різного ступеня вираженості: від малопомітних безсимптомних рубців до патологічних, гіпертрофічних або келоїдних, які викликають естетичні і функціональні порушення. До формування подібного роду рубців призводить зміна нормального перебігу процесу загоєння рани [1]. Апоптоз є морфологічним проявом реалізації внутрішньоклітинної програми самознищення клітини і відрізняється від інших відомих форм загибелі клітини високою організацією і чіткістю молекулярного каскаду реакцій [2]. Апоптоз відіграє важливу роль як в патогенезі шкірних хвороб, так і в підтримці гомеостазу здорової шкіри. Деякі автори вважають, що масова загибель фібробластів шляхом апоптозу сприяє дозріванню тканини келоїду [3, 4]. Маловивченими залишаються процеси проліферації та їх взаємовідношення з апоптозом в молодих келоїдних рубцях, що ростуть. У гіпертрофічних рубцях вони не вивчалися взагалі.

Мета дослідження - вивчення індексу проліферації і апоптозу кератиноцитів епідермісу i клітин різних зон дерми молодих келоїдних рубців епідермісу і дерми гіпертрофічних рубців осіб, що мають ці рубці після оперативних втручань.

Матеріал і методи дослідження. Нами вивчено 35 пацієнтів хірургічного відділення Кримського регіонального управління клінічної лікарні ім. Н.А. Семашко. Хворі перебували на стаціонарному лікуванні у зв'язку з необхідністю проведення різних повторних оперативних втручань в місці попередньої операції. Патологічний матеріал брали інтраопераційно. Сікли післяопераційний рубець і з нього вирізували матер- іал біопсії. Шматочок рубця швидко фіксували $10 \%$ забуферним нейтральним формаліном відразу ж після операції. Матеріал заливали в парафін і з них виготовляли серійні зрізи товщиною 5-6 мкм. Проліферативну активність клітин епідермісу і дерми гіпертрофічних і келоїдних рубців вивчали за допомогою моноклональних антитіл Ki-67 (MIB-1), які ідентифікують ядерний антиген, присутній у більшості проліферативних клітин. Антиген Кі-67, визначений відповідними моноклональними антитілами, короткоживучий протеїн, що руйнується впродовж 1-1,5 години. Завдяки цьому Кi-67 виявляється тільки в клітинах, які діляться, оскільки не встигає накопичуватися і не залишається в спокійних клітинах [5].

Для оцінки процесів програмованої клітинної загибелі в келоїдних рубцях використовували моноклональні антитіла до Fas-рецепторів (CD95/Apo1) і Bcl-2. Головну роль в розвитку апоптозу відіграє так званий "дикий" ("wild") тип гена - онкосупресора wt p53 і кодований ним протеїн p53 [6]. У дослідженнях він використовується для визначення кількості клітин, що знаходяться у стадії апоптозу.

Імуногістохімічні реакції проводили в парафінових зрізах патологічних рубців з використанням відповідних первинних антитіл Ki-67, CD 95/Apo 1, Bcl-2 i p53 (DAKO) і системи візуалізації LSAB (Labelled Streptavidin-Biotin). Ядра дофарбовували гематоксиліном. Теплове демаскування антигенів проводили в мікрохвильовій печі Samsung M1915 NR при фіксованій потужності 800 Вт протягом 2 хвилин. Індекс проліферації і апоптозу вивчали на 40 випадково вибраних полях зору мікроскопа гістологічних зрізів при збільшенні х1350 після підрахунку 1000 
ядер або клітин, відповідно, з подальшим обчисленням показника у відсотках в середньому за наслідками всіх вивчених біоптатів.

Результати й обговорення. У гіпертрофованому епідермісі гіпертрофічного рубця спостерігається активна проліферація клітин паросткового шару. За допомогою моноклонального антитіла Ki 67(MIB-1), яке ідентифікує ядерний антиген, котрий присутній у більшості пролиферативних клітин, визначали індекс проліферації. На 100 епителіоцитів базального шару доводиться 81+0,02 $(81 \%+0,02)$ клітин 3 міткою Кі-67 в ядрі. На 100 епітеліоцитів шипуватого шару доводиться 24+0,001 (24\%+0,001) клітин з міткою Ki-67 в ядрі. У дермі мітка відсутня.

У ядрі клітини існують спеціальні молекулярні сенсори, які реагують на пошкодження ДНК і запускають каскад реакцій, що зрештою служить причиною зупинки клітинного циклу і активації апоптозної загибелі [2]. Активуються репресори клітинної загибелі, головним чинником яких, що реагують на пошкодження ДНК, є білок р53. Активований р53 активує експресію білка Вах і пригноблює експресію Bcl-2 [7]. У здоровій шкірі p53 не виявляється [8]. Білок р53 зустрічається в епідермісі гіпертрофічних рубців в 46+0,01 $(46 \%+0,01)$ клітинах на 100 кліток базального шару і в 9+0,0001 (9\%+0,0001) клітинах на 100 клітин шипуватого шару. У дермі мітка відсутня. Вважається, що в епідермісі саме апоптоз клітин $€$ тим механізмом, який на тлі активної проліферації регулює товщину епідермісу [9]. У гіпертрофічних рубцях процес апоптозу явно не достатній, що призводить до потовщення епідермісу.

Готовність клітин до апоптозу визначається експресією Fas (CD 95 / Аро 1) - рецепторів. Білок Fas (CD 95 / Аро 1) є мембранним рецептором, що за структурою належить до рецепторів сімейства чинника некрозу пухлин [2]. Приблизно 80 амінокислотних залишків утворюють домен смерті (DD), який залучається до білок-білкової взаємодії з білками цитоплазми, генеруючи сигнал смерті. Ген Fas у людини локалізований в довгому плечі 10-ї хромосоми і складається з 9 екзонів. Взаємодія Fas з FAS-L (ліганд) або з моноклональними антитілами призводить до апоптозу клітини [10]. Встановлено, що на 100 кліток базального шару епідермісу гіпертрофічних рубців мітка є на мембранах і в ядрах 42+0,02 $(42 \%+0,02)$ кліток, а на 100 кліток шипуватого шару - в 11+0,001 (11\%+0,001) клітинах. У дермі мітка відсутня.

Негативним регулятором апоптозу, що руйнується каспазами, є Bcl-2 [6]. Шляхом зміни транскрипції промітотичних генів Bcl-2 підтримує клітинний ріст і утруднює входження клітин в клітинний цикл [8, 11]. Він позитивно впливає на транскрипцію генів антиапоптичних білків і одночасно інгібує експресію білків типу Вах і ВН 3 [12]. Bcl-2 подовжує життя клітин, блокуючи апоптоз навіть в умовах стимуляції препаратами хіміотерапій, гіпертермією, чинниками некрозу пухлин і трансфекцією генів р53 або C-myс. Зменшення кількості Bcl-2 індукує розвиток апоптозу [13]. Цей білок $є$ перспективною мішенню для різних маніпуляцій з метою дії на бажану долю клітин. Встановлено, що на 100 клітин базального шару епідермісу гіпертрофічних рубців $27+0,02(27 \%+0,02)$ клітин містять активований даний ген. Отже, 27 клітин із ста не вступлять в апоптоз. У клітинах шипуватого шару і дерми мітка відсутня. Саме інгібітор Bcl-2, який зв'яже його і дозволить Fas-індукованим клітинам вступити в апоптоз, буде патогенетичним лікарським засобом для лікування гіпертрофії епідермісу гіпертрофічних рубців.

В епідермісі молодих келоїдних рубців виявляються активні процеси проліферації. Мітка локалізується в ядрах клітинах базального шару - на 100 клітин доводиться 85+0,01 (85\%+0,01) проліферувальних клітин. У шипуватому шарі бензидинова мітка зустрічається на 100 клітин в 26+0,002 клітинах. У дермі мітка присутня в округлих клітинах, схожих на клітини крові. Вони $€$ в судинах і між колагеновими волокнами зони зростання. Можливо, це проліферувальні клітини судин, які поповнюють популяцію фібробластів [14].

Встановлено, що в епідермісі молодих келоїдних рубців білок р53 експресується в епідермоцитах паросткового шару. На 100 епітеліоцитів базального шару доводиться 95+0,02 (95 \%+0,02) клітин з міткою в ядрі. На 100 епітеліоцитів шипуватого шару виявлено 14+0,001 (14\%+0,001) клітин з міткою. Це свідчить, що, незважаючи на активні процеси проліферації, кератиноцити також активно елімінуються за рахунок процесів апоптозу, який, за нашими даними, відбувається активніше, ніж проліферація. Можливо, через це в келоїдному рубці немає значної гіпертрофії епідермісу.

Експресія білка Fas, що свідчить про те, що епітеліоцити готові до апоптозу, була виявлена в клітинах базального і шипуватого шару (рис. 1). На 100 клітин базального шару мітка локалізується на мембранах і в ядрах 86+0,02 кліток (86\%+0,02). На 100 клітин шипуватого шару доводиться 34+0,002 (34\%+0,002) клітин з мітками в цитоплазмі або в ядрі. У дермі мітки немає.

Bcl-2 негативний регулятор апоптозу, який гальмує вступ клітин до апоптозу [8]. За нашими даними, інгібітор апоптозу Bcl-2 присутній в 


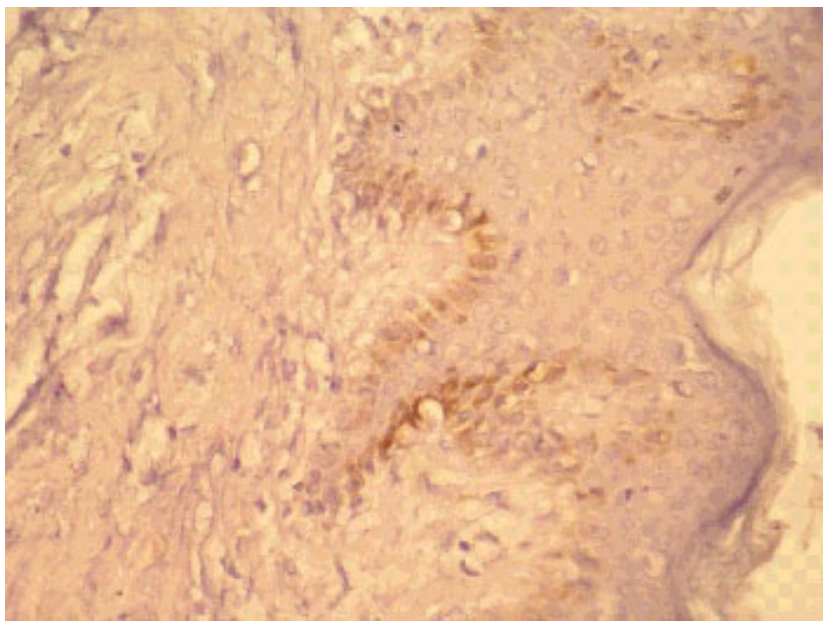

Рис. 1. Fas рецептори на епідермоцитах паросткового шару молодого келоїдного рубця. Забарвлення CD 95 з дофарбуванням ядер гематоксиліном. Візуалізація в системі LSAB. Збільшення: об. 40, ок. 10.

клітинах паросткового шару епідермісу молодих келоїдних рубців. Мітка локалізується в ядрах клітин базального шару. На 100 епітеліоцитів доводиться 96+0,03 (965+0,03) клітин з Bcl-2. На 100 епітеліоцитів шипуватого шару доводиться $11+0,002(11 \%+0,002)$ клітин 3 міткою.

У глибокій зоні і зоні росту дерми зустрічаються округлі клітини з міткою. Такі клітини лежать в капілярах і між колагеновими волокнами поза капілярами. Значить, такі клітини проліферують (у них є Кі 67 позитивні рецептори) і не

\section{ЛITЕРАТУРА}

1. Peled Z.M., Chin O.S., Liu W., Galliano R., Longaker M.T. Response to tissue injury // Clin Plast Surg. -2000. - Vol. 27, № 4. - P. 489-500.

2.Цымбалюк В. И., Медведев В. В. Нейрогенные стволовые клетки. - К.: "Коваль", 2005. - 596 с.

3. Kischer C.W. The microvessels in hypertrophic scars, keloids and related lesions: a review. // J. Submicrosc. Cytol. Pathol. - Vol. 24, № 2, 1992. - 281-296 p.

4. Brown N.J., Willoughby D.A. Apoptosis, necrosis, and proliferation: possible implications in the etiology of keloids // Am. J. patology. - Vol. 149, № 5, 1996. - 1441-1447 p.

5. Cell proliferation in the growing human heart: MIB$1 \mathrm{immunostaining} \mathrm{in} \mathrm{preterm} \mathrm{and} \mathrm{term} \mathrm{infants} \mathrm{at} \mathrm{autopsy/}$ V. Huttenbach, M. L. Ostrowski, D. Thaller, H. S. Kim// Cardiovask. Pathol. - 2001. - Vol. 10, N 3. - P. 119-123.

6. Fesus L. P., Davis J. A., Piacentini M. Apoptosis; Molecular mechanisms in programmed cell death// Europ. J. Cell Biol. - 1991. - Vol. 747. - P. 195-204.

7. Sionov R. V., Haupt Y. The cellular response to p53: the decision between life and death // Ontogene. - 1999. - V. 18. - P. 6145-6157.

8. Снарская Е. С., Молочков В. А. Иммунитет и особенности клеточной иммуногистохимии при базально- и плоскоклеточном раке кожи (Обзор литературы) // Российский журнал кожных и венерических вступають в апоптоз, що підтверджується даними літератури $[15,16]$. Можливо, терапія інгібітоpoм Bcl-2 виявилася б корисною для лікування молодого келоїдного рубця з метою індукції апоптозу в зонах росту, які продукують власне келоїдну тканину.

Висновки. 1. У епідермісі гіпертрофічних рубців процеси апоптозу пригнічені на тлі посиленої проліферації епідермоцитів, що призводить до його гіпертрофії. Збільшений вміст негативного регулятора апоптозу Bcl-2, котрий не дозволяє Fas-індукованим кератиноцитам вступити в апоптоз.

2. В епідермісі молодих келоїдних рубців, незважаючи на активні процеси проліферації, кератиноцити також активно елімінуються апоптозом, що стримує гіпертрофію епідермісу. У зоні росту молодих келоїдних рубців спостерігається активна проліферація клітин, апоптоз яких інгібується Bcl-2.

3. Експресія Bcl-2 і p53 може служити діагностичними маркерами гіпертрофічних і молодих келоїдних рубців.

Перспективи подальших досліджень. Зроблені перші кроки в розумінні місця апоптозу і проліферації в розвитку келоїдних і гіпертрофічних рубців допоможуть в їх ранній диференціальній діагностиці, що важливо для їх лікування. Крім того, розуміння патогенезу формування келоїдних рубців створює основу для вироблення патогенетичної терапії, що впливає на розвиток патологічних рубців.

болезней // 2002. - № 5. - С. 4-9.

9. Казанцева И. А. Апоптоз и его роль в патологии кожи // Российский журнал кожных и венерических болезнейю - 2000. - № 4. - С. 17-22.

10. Роль системы Fas / Fas-L в индукции апоптоза гепатоцитов при хронических вирусных гепатитах / Е.В. Дмитриева, Е.Ю. Москалева, Е.А. Коган, А.О. Буеверов, Н.Н. Белушкина, В.Т. Ивашкин, У.С. Северин, М.А. Пальцев // Арх. пат. - 2003. - № 6. - С. 13-17.

11. Adams J.M., Cory S. The Bcl-2 protein family: arbiters of cell survival// Science. - 1998. - V. 281. - P. 1322-1326.

12. Rich T., Allen R. L., Wylie A. H. Defying death after DNA damage // Nature. - 2000. - V. 407. - P. 777-783.

13. Белушкина Н. Н., Северин С. Е. Молекулярные основы патологии апоптоза // Арх. пат. - 2001. - № 1. - C. 51-59.

14. Келоидные рубцы / В.В. Шафранов, Е.Н. Борхунова, А.В. Таганов, Н.Г. Короткий, В.А. Виссарионов, А.Г. Стенько. М., 2003. - 192 с.

15. Ярилин А. Апоптоз // Эстетическая медицина. - 2004. - T. 3, № 2. - C. 111-123.

16. Chang S. E., Kim K. J., Ro K. H. Sphingosine may have cytotoxic effects via apoptosis on the growth of keloid fibroblasts// J. Dermatol.. - 2004. - Vol. 31. - P. 1-5. 